\title{
The Analysis of Ergonomic Task Demand and Psychosocial Work Factors towards Occupational Safety and Health
}

\author{
Mohd Nasir Selamat, Siti Fardaniah Abd Aziz, Mukhiffun Mukapit, Rogis \\ Baker \& Amar Hisham Jaaffar
}

To Link this Article: http://dx.doi.org/10.6007/IJARAFMS/v11-i3/10870 DOI:10.6007/IJARAFMS/v11-i3/10870

Received: 19 June 2021, Revised: 23 July 2021, Accepted: 14 August 2021

Published Online: 26 August 2021

In-Text Citation: (Selamat et al., 2021)

To Cite this Article: Selamat, M. N., Aziz, S. F. A., Mukapit, M., Baker, R., \& Jaaffar, A. H. (2021). The Analysis of Ergonomic Task Demand and Psychosocial Work Factors towards Occupational Safety and Health. International Journal of Academic Research in Accounting Finance and Management Sciences, 11(3), 191205.

Copyright: @ 2021 The Author(s)

Published by Human Resource Management Academic Research Society (www.hrmars.com)

This article is published under the Creative Commons Attribution (CC BY 4.0) license. Anyone may reproduce, distribute, translate and create derivative works of this article (for both commercial and non-commercial purposes), subject to full attribution to the original publication and authors. The full terms of this license may be seen at: http://creativecommons.org/licences/by/4.0/legalcode

Vol. 11, No. 3, 2021, Pg. 191 - 205

Full Terms \& Conditions of access and use can be found at http://hrmars.com/index.php/pages/detail/publication-ethics 




\title{
The Analysis of Ergonomic Task Demand and Psychosocial Work Factors towards Occupational Safety and Health
}

\author{
Mohd Nasir Selamat ${ }^{1}$, Siti Fardaniah Abd Aziz², Mukhiffun \\ Mukapit ${ }^{3}$, Rogis Baker ${ }^{4}$ \& Amar Hisham Jaaffar ${ }^{5}$ \\ 1,2Human Development Program, Centre for Research in Psychology and Human Well-
} being, Faculty of Social Sciences and Humanities, Universiti Kebangsaan Malaysia, ${ }^{3}$ Faculty of Technology Management and TechnoprenerushipTechnical University of Malaysia Melaka

(Melaka, Malaysia), "4Department of Defence Human Resource Management, Faculty of Defence Studies \& Management, Universiti Pertahanan Nasional Malaysia, ${ }^{5}$ Institute of Energy Policy and Research (IEPRe), Universiti Tenaga Nasional, Malaysia.

Email: daniah@ukm.edu.my

\begin{abstract}
The increase in cases of accidents at workplace, the absence of employees to the work, the rise in illness and high job stress give signs that more urgent action should be taken. If the situation that causes this problem continues, it will certainly also have negative impacts not only on employees, but also on organizations and parties directly related to employees. Occupational safety and health (OSH) aspects are key issues that need to be addressed by organizations. Previous studies have also shown that ergonomics plays an important role with $\mathrm{OSH}$ issues and problems, especially in the manufacturing sector. The implementation of certain initiatives based on ergonomics may provide a way of solving, or alleviating users, safety and health problems in the workplace. This study aimed to examine the ergonomic task demands and psychosocial work factors (PWF) of OSH performance in printing companies. The use of a combination of measurement tools from previous studies has resulted in a special design of questionnaire for this study. Respondents who participated in the study were selected by using stratified random sampling at the printing companies. Two hundred and ninety five respondents from several printing companies in Malaysia were surveyed and analysed. The findings showed that most of the employees were not aware of issues related to ergonomics at work. It was also found that higher job demands contribute to employee stress, accidents and lead to absenteeism problems which representing OSH performance. In addition, the findings showed that shows that PWF (decision authority \& social support) are negatively related to OSH performance. Therefore, several initiatives should be taken by organisation to enhance employee's performance especially in regards to implementation of ergonomics aspects as well as safety and health components.
\end{abstract}

Keyword: Task Factors, OSH Performance, Psychosocial Work Factors, Printing Company 
MANAGEMENT SCIENCES

Vol. 11, No. 3, 2021, E-ISSN: 2225-8329 @ 2021 HRMARS

\section{Introduction}

The development of a borderless world and the movement of sophisticated modern technology promise a variety of changes to be made. Developing countries are also receiving the same impact where changes need to be made in line with the passage of time. This includes developments in the field of occupational safety and health (OSH). For example, in the 18th and 19th centuries, OSH has become an important field in many countries, especially in Western countries. The focus on the development and change of the OHS field in the workplace is becoming increasingly complex. The complexities of today's safety and health hazards mirror the difficulties associated with modern workplace technology in the organisation. It is important to grow a broad range of knowledge, as well as OSH-related skills, to guarantee the well-being of a company's human and other resources.

In the Malaysian perspective, to support the implementation of OSH in the workplace, the Occupational Safety and Health Act of 1994 (OSHA 1994) was introduced. This Act included provisions for securing the safety, health, and welfare of persons at work. It also sought to keep other people against safety and health risks related to the activities of persons at work, and also oversaw the establishment of the National Council for Occupational Safety and Health, which deals with related matters (OSHA, 2010). Thus, under OSHA of 1994 employers assumed accountability for taking care of the health and safety of company workers and workers.

Poor job design, lack of training, and support from organizational management as well as opportunities in decision-making while working can make employees vulnerable to stress and sickness. Unfortunate working conditions are also shown to consequence in innumerable back injuries, stress, and an incidence of accidents (Jia Wern \& Selamat, 2019; Saad, Said \& Abdul-Halim, 2012; Selamat \& Mukapit, 2018; Zakaria, Mansor \& Abdullah, 2012). For instance, in Malaysia, the number of workers involved in workplace/work-related accidents in manufacturing was the highest, with 4,070 cases in 2019 , followed by construction and trading with 5,908 and 5,397 cases, respectively (Department of Occupational Safety and Health, [DOSH], 2019). Empirical report by SOCSO (2018) showed that more than 1000 cases were involved in accidents due to working environment factors such as a bad working surface, unconditional of floors, which considered as a part of ergonomics essentials. Therefore, a call for ergonomic elements, such as workplace design, working environment and high technology machine systems are important on the OSH contexts that may alleviate the occurrence of accidents in the workplace is high.

Ergonomics deals with an application of information about human behaviour, capabilities, and limitations to the design of systems, machines, tools, tasks and environments for productive, safe, and operative human use (Ashraf, Saedd Al-Araimi, \& Bill, 2002; Carayon, 2009; Shaliza et al., 2009). Others define ergonomics as the science of designing the job to fit the worker, instead of forcing the employee to fit the job (Carayon \& Smith, 2000; Occupational Safety \& Health Act [OSHA], 1994; Rowan \& Wright, 1994; Zafir et al., 2013; Selamat, 2016).

It is essential to promote and sustain the highest degree of physical, mental, and social well-being of individuals in all occupations to ensure their performance at workplace (Archer, Borthwick \& Tepe, 2009). Overlooking the importance of maintaining workers health and social well-being at work will lead to numerous difficulties to both the individuals (workers) as well as the organisation (Selamat, 2016). Specifically, this may contribute to a loss of workers' talents and a decline in organisational productivity and performance. 
At an individual level, low levels of health consequences, may affect not only one's own quality life but likewise their relationship with others. In general mental depression will lower person's normal competence to perform but may also drive away friends and family because the negative reaction you may give due to the depression. (Long, 1995; Niedhammer, Chastang \& David, 2008), and contributes to a rise in unemployment. Recent study on health and wellness amongst six Asian countries were included Malaysia had reported that $48 \%$ out of 532 Malaysian respondent suffered from some minor health, while $30 \%$ of Malaysian women and seven per cent of men had serious health issues (News Strait Time on September $20,2015)$. On the other hand, companies with the highest health harms, poor facilities, and environmental issuess as well as a poor workstation will lead to a decline in their employees' work performance (Azman \& Selamat, 2019; Selamat, 2016; Selamat \& Mukapit, 2018). At the end, it could affect organizational such as increase other organizations cost and contributed to lost.

Moreover, problems also happen as a result of a lack of attention to psychosocial work factors (PWF), which contributes to the likelihood of workers getting involved in safety problem such as accidents, as well as experiencing stress, absence doing their work, depression and fatigue (Annalisa et al., 2013; Bartram, Yadegarfar \& Baldwin, 2009; Kefri \& Selamat, 2021; Selamat \& Mukapit, 2018). Work ineffectiveness, working discomfort, health problems actually can be influenced by PWF (Rugulies et al., 2007; Larsman \& Hanse, 2009) which eventually affect the overall workers well-being. As stated in the study by Kadir Ariffin et al (2020) that are the responsibility of key parties in the organization such as organizational management, supervisors and colleagues have an important role in improving the level of employee safety. Therefore, in an effort to prevent safety and health-related problems through an ergonomic approach in the workplace, due attention must be given seriously to PWF (Selamat, 2016).

The purpose of this study to attempt on does ergonomic task demand and psychosocial work factors affect occupational safety and health performance? This study seeks to expand the body of academic knowledge in evaluating OSH performance. Past study had mentioned that theory has shown three indicators, namely absenteeism, sickness, and occupational stress as major concerns of workers' outcome. Additionally, workplace accidents were found to be the most important measure of OSH performance (Ahmadon et al., 2006; Archer et al., 2005; Selamat et al., 2020). Therefore, this study also intends to include occupational accidents as another indicator of OSH performance as this has yet to be done.

This study hopes to understand the practical implementation of $\mathrm{OSH}$ at the organization in the Malaysian context. The priority is given in Malaysia, to evaluate the applications of $\mathrm{OSH}$ in the workplace that are still infrequent. As a major concern in this study that would contribute to give an organisation especially in the human resource department as an indication to the importance of different factors and not just a factor in determining OSH performance. It might help the managers in systematizing the process of work and support them towards providing a good decision related to the workers and job issues. Most importantly, the findings of this study aim to encourage organisations to improve their human resource performance by creating a safety workplace, and a well-organized work system by taking into account relevant psychosocial features.

\section{Literature Review}

An ergonomic work system provides a way of describing all of the fundamentals of work that affect workforces and outcomes. Eric and Curt (2008) stated ergonomics as systematic 
MANAGEMENT SCIENCES

Vol. 11, No. 3, 2021, E-ISSN: 2225-8329 @ 2021 HRMARS

applications and limitations to the design of systems with the aim of optimising the interaction between persons and other system elements to enhance safety, performance, and satisfaction.

In this study, work system refers to the elements of task factors or demand, individual factors, and organisational factors (Carayon, 2009; Smith \& Carayon, 1989). This is based on the work system model concerning tasks performed by an individual using tools and technologies, the tasks performed in a physical environment and under organisational conditions (Smith \& Carayon, 1989). Other than that, PWF has been described as how workers and managers perceive work organisation (Toomingasm et al., 1997). Karasek and Theorell (1990), as well as Johnson and Hall (2006) described that PWF exposure conditions contain mental demands, level of control, and social support at workplace. In this study, PWF is defined to include decision authority and social support.

According to Spector (2008) performance refers to the achievement of employee's behaviour while doing their work in good condition and it also depends on the employee's ability to be able to perform under simulated conditions. It refers to behavioural aspects that contribute outcomes to the company or organisation (Cambell, 1993). In addition, OSH refers to an act of creating further provisions for securing the safety, health and well-being of persons at work, and for protecting others against risks and hazard to safety or health in connection with the activities of individuals at work (OSHA, 2010). The purpose of OSH is to establish the National Council for Occupational Safety and Health and for matters connected therewith (OSHA, 2010).

In other words, it means promoting and maintaining the highest degree of physical, mental, and social well-being of employees in all occupations (Archer et al., 2005). The current study describes OSH performance as the look on the restraint in preserving and protecting individual workers and facility resources at the workplace including social, mental, physical, and well-being aspects (Kohn, Friend \& Winterberger, 1996). It also emphases on preventing the occurrence of several safety and health-related problems including: absenteeism, sickness, occupational stress, and occupational accidents (Selamat, 2016: Selamat \& Mukapit, 2018).

\section{Methodology}

This study adopted the descriptive study approach, offering a profile, or a description, of relevant aspects of the phenomena of interest to the researcher from the perspective of the individual, company or organization, industry, or other relevant body (Sekaran, 2000). The study also touched upon individual behaviour. Thus, the quantitative method was used as the core method to analyse data from respondents.

In studying the relationship between task factors or demand, PWF and OSH performance, the research population was considered to be all the workforces in printing companies in Malaysia. The total number of employees in printing companies in Malaysia is 47,102 employees (DOSM, 2006) in 3162 printing companies that have registered with the Home Affairs Ministry of Malaysia (2002). The lists of printing companies were obtained from the Registrar of Companies (ROC) and also from the Malaysian Printers Association (MPA).

This study was also involved the main respondent which is the production line workers; refer to the individuals involved in operations of the production department. This includes those who operate related any printing machines, folding machines, and binding machines as well as all other workforces who are associated with production departments/units. This study conducted using stratified random sampling that assists in 
MANAGEMENT SCIENCES

Vol. 11, No. 3, 2021, E-ISSN: 2225-8329 @ 2021 HRMARS

estimating the population parameters and identifying the subgroup of elements within the population. The process of selection the population based on the list of companies provided by MPA and ROC. Every companies were distributed 15 to 20 set of questionnaire to the potential respondents depended on the size of the organisation or companies. Therefore, it was randomly selecting the organisation followed by the State which to address the fact that there is wide variance in the number of companies located by the different State. Yet, the total of workers $(47,102$ workers) in printing companies in Malaysia provided by DOSM (2006) was used as standard in order to achieve the sample size of study. Thus, as reported by DOSM the estimated total number of the population is 37,682 employees and the sample size is therefore estimated at 381 respondents. At the end, the study successfully received completed questionnaires from 383 respondents but only 295 are useable.

In this study, a set of questionnaires was created to determine the relationship between task factors or demands, PWF toward OSH performance. Moreover, this study adapted certain approaches to ensemble the context of the study. This means that several elements from others studies were utilized to support in measuring variables in these study. In addition, the five-point Likert scale was used to measure every item in the questionnaire. The Likert scale consists of statements that express either a favourable or an unfavourable attitude toward the object of interest (Cooper \& Schindler, 2008; Sekaran \& Bougie, 2010). In other words, subjects are asked to agree or disagree with each item or statement in the questionnaire. Hence, each response is given a numerical mark reflecting the degree of agreement or disagreement, and the scores can be added together to ascertain the participant's overall attitude (Cooper \& Schindler, 2008).

OSH performance is related to the ability and certain behavioural parts that contribute to several outcomes. It can be referred such as promoting and maintaining a high degree of physical, mental, and social well-being among workers. However, the current study defines $\mathrm{OSH}$ performance as matters related to a number of specific OSH aspects. Therefore, in this study to define OSH performance will only focus on absenteeism, sickness, occupational stress, and occupational accidents. In measuring task factors, it is refer to the work system model which represented as quantity demand and sensorial demand on the individual workers. The total item was used in these measurement was 18 items with the worthy value of Cronbach alpha (0.74). Meanwhile in measuring PWF, study were used the definition on how the workers feel in doing their jobs which included the aspects of decision authority, supervisor support, and the support of peers (social support) and the value of Cronbach alpha was 0.84. In measuring ergonomic task factor or demand, this describes part of the factors at work that affect employees and outcome (OSH performance). It is stated that the work system model places psychosocial, cognitive, and physical loads on the individual. Moreover, the work system model is utilized as an instrument to measure employee's outcome through factors such as task factors, organizational factors, and individual factors. Therefor task factor in the work system was choosing that presenting as ergonomic task factors or demands.

Regarding the analysis process, Hair et al (2006) stated that multiple regressions refer to a statistical technique, which analyses the linear relationship between a single dependent (criterion variable) which included several independent (predictor) variables. The main purpose of multiple regression analysis is to predict how dependent variables change in response to changes in the independent variables. According to Hair et al (2006), in applying multiple regression analysis, two principles need to be given attention which refer to (1) the data must be metric or appropriately transformed, and (2) before deriving the regression equation, the researcher must decide which variable is to be dependent, and which remaining 


\section{MANAGEMENT SCIENCES}

Vol. 11, No. 3, 2021, E-ISSN: 2225-8329 @ 2021 HRMARS

variables are independent. Thus, multiple regressions were also used to determine the relationship between the measurements of task factors or demand, PWF - referred to as independent variables, toward OSH performance - referred to as dependent variables.

\section{Result \& Discussions}

After several analyses had done, the final result shown as below. Table 1.0 shows the profiles of the respondents. Fewer than $2 \%$ of those involved in the study were below 20 years of age, with the youngest respondent aged 17. Result shows about $6 \%$ of respondents were aged 51 or older, with the oldest respondent aged 58 . The mean age was 35.34 years (SD $=8.93)$. The common of respondents were in the 31 to 40 years age group (36.3\%), followed by those in the 21 to 30 years age group (35.6\%). Twenty point seven percent of respondents were aged between 41 and 50 . Most of the respondents were male with a rate of $87.5 \%(n=258)$, compared to females at $12 \%(n=37)$.

According to Table 1.0 more than half of the respondents $(68.1 \%)$ were married, whereas $29.8 \%$ were still single, $1.4 \%$ divorced, and $0.7 \%$ widowed. The vast majority of respondents (93.9\%) were ethnically Malay, while fewer than $2 \%$ were Chinese and only $2 \%$ Indian. Of the study subjects, $37.6 \%$ had worked in their company or organisation for five years or less, $18.9 \%$ between 6 and 10 years, and less than $16 \%$ for both 11 to 15 years and 16 to 20 years. The results also revealed that $12.6 \%$ of the respondents $(n=38)$ had worked for more than 20 years in their company, with a longest-serving period of 40 years. The mean of length of service of workers was 10.91 years (SD $=8.97$ ). 
MANAGEMENT SCIENCES

Vol. 11, No. 3, 2021, E-ISSN: 2225-8329 @ 2021 HRMARS

Table 1.0

Profiles of the Respondents

\begin{tabular}{|c|c|c|c|}
\hline $\begin{array}{l}\text { Respondent' } \\
\text { s brofiles }\end{array}$ & Categories & Frequency & $\begin{array}{r}\text { Percen } \\
t(\%)\end{array}$ \\
\hline \multirow[t]{5}{*}{ Age } & Below 20 years old & 3 & 1 \\
\hline & $21-30$ years & 105 & 35.6 \\
\hline & $31-40$ years & 107 & 36.3 \\
\hline & $41-50$ years & 61 & 20.7 \\
\hline & Above 51 years old & 19 & 6.4 \\
\hline \multirow{2}{*}{ Gender } & Male & 258 & 87.5 \\
\hline & Female & 37 & 12.5 \\
\hline \multirow[t]{4}{*}{ Marital } & Single & 88 & 29.8 \\
\hline & Married & 201 & 68.1 \\
\hline & Divorced & 4 & 1.4 \\
\hline & Widowed & 2 & 0.7 \\
\hline \multirow[t]{4}{*}{ Ethnic Group } & Malay & 277 & 93.9 \\
\hline & Chinese & 5 & 1.7 \\
\hline & Indian & 7 & 2.4 \\
\hline & Others & 6 & 2 \\
\hline \multirow[t]{5}{*}{ Length of Service } & 5 years or less & 111 & 37.6 \\
\hline & $6-10$ years & 56 & 18.9 \\
\hline & $11-15$ years & 46 & 15.6 \\
\hline & $16-20$ years & 44 & 14.9 \\
\hline & More than 20 years & 38 & 12.9 \\
\hline \multirow[t]{7}{*}{ Education Level } & Bachelor or higher & 11 & 3.7 \\
\hline & Diploma / Professional or & 89 & 30.2 \\
\hline & Technical Certificates & & \\
\hline & Secondary & 184 & 62.4 \\
\hline & (MCE/SPM/PMR/SRP/LCE) & & \\
\hline & Primary school & 6 & 2 \\
\hline & Others & 5 & 1.7 \\
\hline \multirow{2}{*}{$\begin{array}{l}\text { Involvement } \\
\text { in accident }\end{array}$} & Yes & 103 & 34.9 \\
\hline & No & 192 & 65.1 \\
\hline
\end{tabular}

Referring to an education levels, 11 people (3.7\%) hold a bachelor or higher degree, 89 people (30.2\%) graduated with a diploma or some technical or professional certification. Majority of respondents, 184 people (62.4\%), only received a secondary school education, while six people (2\%) were only educated to the primary school level. Lastly, 103 respondents (34.9\%) had experienced an accident at workplace, while the remaining 192 (65.1\%) had not. They are many types of accidents cited by respondents which more than 10 times were slipping, cutting of fingers, stumbling, and hands and legs being caught. These may seem like minor accidents but they can still have effects on worker's performance.

\section{The Relationship between task factors or demands and OSH Performance}

Result shows that the PWF dimensions to be significantly related (quantity demand and sensorial demand) to OSH performance (occupational stress, sickness, occupational accidents, absenteeism). Table 2.0 summarizes the regression results for all four dimensions of OSH performance. 
MANAGEMENT SCIENCES

Vol. 11, No. 3, 2021, E-ISSN: 2225-8329 @ 2021 HRMARS

Table 2.0: Multiple Regression Analysis Results for the Relationship between Task Factors and OSH Performance

\begin{tabular}{|c|c|c|c|c|}
\hline \multirow[b]{2}{*}{ (B) } & \multirow[b]{2}{*}{$\begin{array}{l}\text { Occupational } \\
\text { Stress }\end{array}$} & \multicolumn{2}{|c|}{ OSH Performance } & \multirow[b]{2}{*}{$\begin{array}{l}\text { Absenteeism } \\
\text { (B) }\end{array}$} \\
\hline & & $\begin{array}{c}\text { Sickness } \\
\text { (B) }\end{array}$ & $\begin{array}{l}\text { Occupational } \\
\text { Accidents } \\
\text { (B) }\end{array}$ & \\
\hline Task factor & & & & \\
\hline Quantity Demands & $.51 * *$ & $.24 * *$ & $.18^{* *}$ & $.19 * *$ \\
\hline Sensorial Demands & -.02 & .02 & $-.23 * *$ & -.09 \\
\hline$R^{2}$ & .33 & .10 & .12 & .06 \\
\hline$F$ & $20.83^{* *}$ & $4.59 * *$ & $5.66 * *$ & $2.82 * *$ \\
\hline
\end{tabular}

Note: $n=295 .{ }^{*} p \leq .05,{ }^{* *} p \leq .01, * * * p \leq .001$

The study predicted that task factors had an impact on OSH performance, and would eventually provide improvements for workers and organizational performance. As mentioned in earlier studies, ergonomics implemented effectively can have a positive impact on an organization and its employees, which can improve overall human performance (Loo \& Richardson, 2012; Kogi, 2012; Majorkumar et al., 2001; Shaliza et al., 2009).

Occupational Stress - The task factors significantly predicted occupational stress and explained $33 \%$ of the variance in occupational stress. The overall regression model was significant, $R 2=.33, F(7,287)=2.83, p<.001$. Especially on quantity demand $(\beta=.51, p=$ $.00)$ is positively significant towards occupational stress. Yet, sensorial demands were not significant $(\beta=-.02, p=.69)$, It is clear that increasing the number of tasks or duties assigned to employees can result in increased stress, leading to unfortunate health. This finding is consistent with past studies, which reported that the burden of work load increases worker's stress (Ahsan et al., 2009; Edimansyah, 2008; Salleh et al., 2008; Yahaya et al., 2010).

Sickness - The overall regression model was significant, $R 2=.10, F(7,287)=4.5, p<$ .001. Quantity demands had showed a significant positive relationship to sickness $(\beta=.24, p$ $=.00)$ while sensorial demands $(\beta=.02, p=.71)$ are not significant, this consequence is similar to that found in other studies, which reported that sickness among employees is elevated when the burden of tasks at work is increased (Shaliza et al., 2009; Zafir et al., 2013). As mentioned by Morgan et al (1976), workers sickness is associated to organization's failure to distribute a suitable amount of capability to the employees.

Occupational Accident - The overall regression model was significant, $\mathrm{R} 2=.12, \mathrm{~F}$ $(7,287)=5.66, p<.001$. There are only two dimensions were found to be significant, namely quantity demands was positively significant $(\beta=.18, p=.00)$, sensorial demands was to be negatively significant $(\beta=-.23, p=.00)$ toward occupational accident. However, the relationship of the variables is at the contradictory direction. Based on the result shown that when the types of work is challenging such as in this highly required concentration in work, work may be perceived to be pleasurable and non-monotonous that eventually avoids workers to involve with any risk and hazard as well as accident. Working in the happy mood was found to reduce injuries, danger, as well as accident (Arnold \& Evangelia, 2008; Davis, 2000; Hwajin, Sujin \& Alice, 2013).

Absenteeism - The overall regression model was significant, $R 2=.06, F(7,287)=$ 2.82, $p<.001$. Quantity demands $(\beta=.19, p=.00)$ is positively significant towards absenteeism. Moreover, sensorial demand $(\beta=-.09, p=.12)$ are not significantly towards absenteeism. Results also shows that quantity demand is positively significantly towards 
MANAGEMENT SCIENCES

Vol. 11, No. 3, 2021, E-ISSN: 2225-8329 @ 2021 HRMARS

absenteeism, which is consistent with earlier studies that had reported task demands cause tiredness, frustration, obstruction and a feeling of being overwhelmed, which and the end can lead to worker's absenteeism (Harrison \& Martopcio, 1998; Luz \& Green, 1997). Some workers also claimed that their involvement in accidents in the workplace led to them not attending work due to getting a future health treatment and medical certificate.

\section{The Relationship between PWF and OSH Performance}

Referring to the next objective of study is to identify the relationship of PWF toward OSH performance. Result indicated the relationship between PWF and OSH Performance shows that PWF (decision authority \& social support) are negatively related to OSH performance. The results, as illustrated in Table 3.0.

Table 3.0: Multiple Regression Analysis Results for the Relationship between PWF and OSH Performance

\begin{tabular}{lcccc}
\hline & \multicolumn{4}{c}{ OSH Performance } \\
\cline { 2 - 5 } & $\begin{array}{l}\text { Occupational } \\
\text { Stress }\end{array}$ & $\begin{array}{c}\text { Sickness } \\
(\boldsymbol{B})\end{array}$ & $\begin{array}{l}\text { Occupational } \\
\text { Accidents } \\
(\boldsymbol{B})\end{array}$ & $\begin{array}{c}\text { Absenteeism } \\
(\boldsymbol{B})\end{array}$ \\
\hline Decision Authority & $-.32^{* *}$ & $-.19^{* *}$ & .10 & -.21 \\
Social Support & -.03 & .06 & -.02 & .02 \\
\hline$R^{2}$ & .11 & .03 & .01 & .00 \\
$F$ & $18.21^{* *}$ & $5.15^{* *}$ & 1.28 & .06 \\
\hline
\end{tabular}

Note: $n=295 .{ }^{*} p \leq .05,{ }^{* *} p \leq . .01,{ }^{* * *} p \leq . .001$

The overall regression model was significant, $R 2=11, F(2,292)=18.22, p<.000$. Result presented that decision authority negatively significant $(\beta=-.32, p=.00)$ toward occupational stress, while social support $(\beta=-.03, p=.55)$ were not significant.

Referring to the dimension of sickness shows the overall regression model was significant, $R 2=.03,(F=5.15, p=.01)$. There was a negatively significant of decision authority $(\beta=-.19, p=.00)$ toward sickness as well as the dimension of social support was not significant $(\beta=.06, p=.27$ ) toward sickness. While occupational accidents were found to not significantly for both dimensions of PWF too. The overall regression model was significant, $R 2=.01,(F=1.28, p=.28)$. Decision authority $(\beta=.10, p=.11)$ and social support $(\beta=-.02$, $p=.75)$ toward occupational accident. Finally for the absenteeism shows the overall regression model was significant, $R 2=.00,(F=.06, p=.94)$. Decision authority $(\beta=-.21, p=$ .73) was found to not significant toward absenteeism and social support ( $\beta=.02, p=.99)$ was also insignificant towards absenteeism. These results disclose that absenteeism cannot be blamed on the limited of having support and the involvement of employees in making decisions connected to their duty or task. It can be say that health problem, family issues and individual problem could be the reasons of employees absent from work (Silverstein, 2008 \& Weichel et al., 2009). According to Zafir (2014) had mentioned that occupational stressors are significantly, but negatively, related to individual productivity, including work relationships; work-life balance; job security which actually related the other elements of PWF among employees.

A study on systematic reviews has found the inconsistency of PWF toward health, particularly on the blood pressure of workers (Gilbert-Ouimet, 2014; Landsbergis et al., 
MANAGEMENT SCIENCES

Vol. 11, No. 3, 2021, E-ISSN: 2225-8329 @ 2021 HRMARS

2013). Hereafter, Warren (2004) claimed that evidence for the relationship of the roles PWF in developing employee's health are still not clearly understood. For example, study indicated from the 22 studies of the PWF toward health, 13 have showed insignificant consequence (Landsbergis et al., 2013). These shown inconsistencies of the result of studies and it might go to the current of study.

\section{Conclusion}

Although OSH performance was considered of great significance in the printing companies, with each company striving to avoid problems related to OSH at workplace, most respondents were not alert of the term 'ergonomics', nor did they understand the importance and the significance of ergonomics to the individual as well as to an organisation. Most respondents assumed that ergonomics was similar to $\mathrm{OSH}$ at workplace, relating for example to the wearing all the personal protection equipment such as safety shoes, ear protection and being aware of the dangers of chemicals in the workplace. Indeed several previous studies of ergonomics in Malaysia found that the level of awareness of the topic among workers was low (Rahman \& Selamat, 2020: Loo \& Richardson, 2012; Jia Wern \& Selamat, 2020; Rozlina et al., 2012; Selamat, 2016: Shaliza et al., 2009; Zafir \& Durishah, 2009).

The implementation of training programs had shown a significant on the development of knowledge and awareness of employees on a subject. In the context of occupational safety and health, safety training is important and should be done in every organization so that the relevant elements can be used while performing tasks in the workplace. The study found that organizations need to ensure that employees' duties support the use of knowledge and skills learned in training so that the training provided can stimulate learning motivation and beneficial to both employees and employers (Siti-Fardaniah, 2018). On the other hand, with a good communication among higher management and employees will turn positively enhance safety culture at work which eventually leads to best performance of employees (Zitty et al., 2019).

On the top of view, it would be interesting to replicate this study with future modifications. This would best take the form of a thorough investigation of the occurrence of $\mathrm{OSH}$ problems at workplace through a longitudinal study which are focusing on OSH before and after its implementation, and would include the ergonomic aspects owing to the importance of implementing ergonomics at the organisation. As a final point, the used of meta-analysis approaches, may defining a good context OSH performance at work. The generalization of the concept task factors, PWF and OSH performance could improve the development of knowledge study in the manufacturing industry (specifically in the printing companies) and to the other organizations. At the end, the enlargement of data, facts, and information affect to the sustaining safety and health aspect at work in future.

\section{Acknowledgement}

Special thanks to Universiti Kebangsaan Malaysia that supported this research under Encouragement Research Grant (Geran Galakan Penyelidikan: GGP-2020-028) and Young Researcher Encouragement Research Grant (Geran Galakan Penyelidik Muda: GGPM-2017067).

\section{References}

Ahmadon, B., Rosli, M. Z., Mohd-Saidin, M., \& Abdul-Hakim, M. (2006). Occupational safety and health (OSH) management systems: towards development of safety and 
MANAGEMENT SCIENCES

Vol. 11 , No. 3, 2021, E-ISSN: 2225-8329 @ 2021 HRMARS

health culture. Proceedings of the Sixth Asia-Pacific Structural Engineering and Construction Conference (APSEC 2006), 5-6 September 2006, Kuala Lumpur.

Ahsan, N., Abdullah, Z., Gun-Fie, D. Y., \& Shah-Alam, S. (2009). A study of job stress on job satisfaction among university staff in Malaysia: Empirical study. European Journal of Social Sciences, 8(1), 121.

Annalisa, C., Isabelle, G., Els, C., \& France, K. (2013). Gender difference in sickness absence from work: a multiple mediation analysis of psychosocial factor. European Journal of Public Health, 23(4), 635-642.

Archer, R., Borthwick, K., \& Tepe-Susanne. (2009). OS\&H a management guide. Engage Learning Australia 2009.

Arnold, B. B., \& Evangelia, D. (2008). Towards a model of work engagement. Career Development International, 13(3), 209-223.

Ashraf, S., Saedd, Al-Araimi., \& Bill, O. (2002). Development of a software package for ergonomic assessment of manufacturing industry. Computer \& Industrial Engineering Journal, 43, 485-493.

Azman, M. A. A., \& Selamat, M. N. (2019). Sistem kerja ergonomik dan prestasi keselamatan dan kesihatan pekerjaan dalam Industri Pembuatan. Jurnal Wacana Sarjana, 3(2): 1-1.

Bartram, D. J., Yadegarfar, G., \& Baldwin, D. S. (2009). Psychosocial working conditions and work-related stressors among UK veterinary surgeons. Oxford Journals Medicine Occupational Medicine, 59(5), 334-341.

Campbell, J. P., McCloy, R. R., Oppler, S. H., \& Sager, C. E. (1993). A theory of performance. In E.Schmitt, W. C. Borman, \& Associates, (Eds). Personnel selection in organizations. San Fracisco: Jissey-Bass. 35-70.

Carayon, P. (2009). The Balance Theory and the Work System Model... Twenty years later. INTL. Journal of Human-Computer Interaction, 25(5), 313-327.

Carayon, P., Xie, A., \& Kianfar, S. (2014). Human factors and ergonomics as a patient safety practice. BMJ Quality Safety, 23, 196-205.

Cooper, D. R., \& Schindler, P. S. (2008). Business research methods 10th Edition. McGraw-Hill International Edition, Boston.

Davis, K. G., \& Heaney, C. A. (2000).The relationship between psychosocial work characteristics and low back pain: underlying methodological issues. Clinical Biomechanics, 15(6), 389-406.

Edimansyah. (2008). Assessing and managing risk of occupational stress in male automotive assembly workers in Malaysia. Unpublished doctoral dissertation, Universiti Putra Malaysia.

Eric, F. S., \& Curt, C. B. (2008). What is Human Factors and Ergonomics? Benchmark research \& safety. www.benchmarkrs.com

Gilbert-Ouimet, M., Trudel, X., Brisson, C., Milot, A., Vézina, M. (2014). Adverse effects of psychosocial work factors on blood pressure: systematic review of studies on demand-control-support and effort-reward imbalance models. Scanadian Journal Work Environmental Health, 40(2), 109-132.

Hair, J. M., Black, W. C., Babin, B. J., Anderson, R. E., \& Tatham, R. L. (2006). Multivariate Data Analysis (6th ed). Upper Saddle River, NJ: Pearson Prentice Hall.

Harrison, D. A., \& Martocchio, J. J. (1998). Time for absenteeism: A 20-year review of origins, offshoots, and outcomes. Journal of Management, 24(3), 305-350.

Hwajin, Y, Sujin, Y., \& Alice, M. I. (2013). Positive affect improves working memory: Implications for controlled cognitive processing. Cognition and Emotion, 27(3), 474-482. 
MANAGEMENT SCIENCES

Vol. 11, No. 3, 2021, E-ISSN: 2225-8329 ๔ 2021 HRMARS

Jia Wern, M. K., \& Selamat, M. N. (2019, October 19). Sistem kerja ergonomik dan prestasi keselamatan dan kesihatan pekerjaan dalam Industri Pembuatan di Klang, Selangor. Jurnal Wacana Sarjana, 3(1), 1-14.

Johnson, J. V., \& Hall, E. M. (2006). Job strain, work place social support, and cardiovascular disease: A cross-sectional study of a random sample of the Swedish working population. American Journal of Public Health, 78(10).

Loo, H. S. \& Richardson, S. (2012). Ergonomics issues in Malaysia. Journal of Social Sciences, 8(1), 61-65.

Landsbergis, P. A., Dobson, M., Koutsouras, G., \& Schnall, P. (2013). Job strain and ambulatory blood pressure: a meta-analysis and systematic review. American Journal Public Health, 103(3), e61-71.

Kadir, A., Norfadillah, D., \& Kadaruddin, A. (2020). Analisis Penilaian Iklim Keselamatan Pekerja di Bahagian Operasi Sistem Pengangkutan Rel Bandar Malaysia. Akademika 90 (Isu Khas 1/Special Issue): 103-113

Karasek, R. A., \& Theorell, T. (1990). Health Work. Basic Book, New York.

Kefri, M. S. N., \& Selamat, M. N. (2021). Hubungan antara sistem kerja ergonomik dan prestasi keselamatan dan kesihatan pekerjaan (KKP) di Industri Pembuatan. Jurnal Wacana Sarjana, 5(1), 1 - 11.

Khon, J. P., Friend, M. A., \& Winterberger, C. A. (1996). Fundamental of occupational safety and health. Industrial Technology Department, East Carolina University, Greenville, North Carolina.

Kogi, K. (2012a). Practical ways to facilitate ergonomics improvements in occupational health practice. Human Factors, 54(6), 890-900.

Larsman, P., \& Hanse, J. J. (2009). The impact of decision latitude, psychological load and social support at work on the development of neck, shoulder and low back symptoms among female human service organization workers. International Journal of Industrial Ergonomics, 39, 442-226

Long, B. C. (1995). Stress in the workplace. Eric Digest EDO-CG-95-81.

Luz, J., \& Green, M. S. (1997). Sickness absenteeism from work-a critical review of the literature. Public Health Reviews, 25(2), 89-122.

Majorkumar, G., Arunkumar, P., \& Anil, M. (2001). Quality improvement in manufacturing through human performance enhancement. Integrated

Manufacturing Systems 12/5: 360-367. MCB University Press.

Morgan, L. G., \& Herman, J. B. (1976). Perceived consequences of absenteeism. Journal of Applied Psychology, 61(6), 738-742.

Niedhammer, I., Chastang, J. F., \& David, S. (2008). Importance of psychosocial work factors on general health outcomes in the national French SUMER survey. Occupational Medicine, 58, 15-24.

Pertubuhan Keselamatan Sosial (PERKESO). (2018). Laporan Tahunan. Retrieved 2 January 2020, from https://www.perkeso.gov.my/index.php/ms/ laporan/laporanTahunan.

Rahman, N. A., \& Selamat, M. N. (2020). Sistem kerja ergonomik, prestasi keselamatan dan kesihatan pekerjaan di Industri Pembuatan Malaysia. Jurnal Wacana Sarjana, 4(2), 1

Rowan, M. P., \& Wright P. C. (1994). Ergonomic is good for business. Work Study, 43(8), 7-12. MCB University Press.

Rozlina, M. D., Awaluddin, M. S., SA-Hamid, S. H., \& Norhayati, Z. (2012). Perception of ergonomics important at workplace san safety culture among safety \& health 
MANAGEMENT SCIENCES

Vol. 11, No. 3, 2021, E-ISSN: 2225-8329 @ 2021 HRMARS

Practitioners in Malaysia. Proceeding of the World Congress on Engineering, 1.

Rugulies, R., Christensen, K. B., Borritz, M., Villadsen, E., Bultmann, U., \& Kristensen, T. S. (2007). The contribution of the psychosocial work environment to sickness absence in human service workers: Result of a 3-year follow-up study. Work \& Stress, 21(4), 293311.

Saad, M. S., Said, F., \& Abdul-Halim, Z. (2012). The determinants of industrial accidents in the Malaysian manufacturing sector. African Journal of Business Management, 6(5), 19992006.

Selamat, M. N. (2016). Ergonomic work system and occupational safety and health performance: Mediating effect of psychosocial work factor. Ph.D Thesis, Malaysia Universiti Sains Malaysia. Penang.

Selamat, M. N., \& Mukapit, M. (2018). The relationship between task factors \& occupational safety and health (osh) performance in the Printing Industry. Akademika, 88(3), 65-76.

Selamat, M. N. (2013). The determinant of OSH performance: A study on ergonomic work system. Journal Occupational Environmental Medicine, 70.

Selamat, M. N., Mukapit, M., Abd-Aziz, S. F, \& Zafir, K. M. M. (2019). Re-definition of

occupational safety and health performance in Malaysian Manufacturing Industry. International Journal of Recent Technology and Engineering (IJRTE) ISSN: 2277-3878, 8, $2 \mathrm{~S} 10$.

Selamat, M. N., Akhir, N. M., Abdul Aziz, S. F., Jaaffar, A. H., \& Baker, R. (2020). Reliable dimensions of ergonomic work system in the Malaysian Manufacturing Industries. International Journal of Academic Research in Economics \& Management Sciences. 9(2), 102-112.

Sekaran, U. (2010). Research methods for business: A Skill-building Approach, (5rd ed). USA: John Wiley and Sons, Inc.

Silverstein, M. (2008). Meeting the challenges of an aging workforce. American Journal of Industrial Medicine, 51, 269-28.

Siti-Fardaniah, A. A. (2018). Bagaimana organisasi boleh memotivasikan pekerja untuk belajar dalam latihan: Persepsi ahli akademik. Akademika, 88(2), 5-20.

Shaliza, A. M., Shahrul, K., Zalinda, O., \& Mohzani, M. (2009). The effect of ergonomics applications in work system on mental health of visual display terminal workers. European Journal of Scientific Research, 31(3), 341-354.

SOCSO. (2013). Annual Report Social Security Organization

Spector, P. E. (2008). Industrial and organizational psychology. 5th Edition. John Wiley \& Sons, LTD.

Toomingas, A., Theorell, T., Miche'lsen, H., \& Nordemar, R. (1997). Associations between selfrated psychosocial work conditions and musculoskeletal symptoms and signs, Scandinavian Journal Work Environmental Health, 23, 130-139.

Warren, J. R., Hoonakker, P., Carayon, P., \& Brand, J. (2004). Job characteristics as mediators in SES-health relationships. Social Science \& Medicine, 59, 1367-1378.

Weichel, J., M. Buch, D. Urban, \& E. Frieling. (2009). Sustainability and the ageing workforce: Considerations with regard to the German Car Manufacturing Industry. In Creating Sustainable Work Systems, edited by P. Docherty, M. Kira and A. B. Shani, 70-83. New York: Routledge.

Zakaria, N. H., Mansor, N., \& Abdullah, Z. (2012). Workplace accident in Malaysia: Most common causes and solutions. Business and Management Review, 2(5), 75- 88.

Zafir, M. M. (2014). Measuring the effect of commitment on occupational stressors and 
individual productivity ties. Jurnal Pengurusan, 40, 103-113.

Zafir, M. M., Nor-Liza, A., \& Zizah, C. S. (2013). Ergonomics and stress at workplace: engineering contributions to social sciences. Jurnal Pengurusan, 37, 125-131.

Zitty, S. I., Kadir, A., Mazhani, M., \& Lui, M. J. (2019). Analisis keberkesanan komunikasi dalam meningkatkan keselamatan dan kesihatan pekerjaan di universiti penyelidikan di Malaysia. Akademika, 89(3), 183-194. 